\title{
Lean assemble-to-order manufacturing at Ericsson
}

\section{Maria Westin}

Industrial Logistics, Luleå University of Technology, SE-971 87 Luleå, Sweden and AstraZeneca AB, SE-151 85 Södertälje, Sweden E-mail: westin.e.maria@gmail.com

\section{Diana Chronéer and Anders Segerstedt*}

\author{
Industrial Logistics, \\ Luleå University of Technology, \\ SE-971 87 Luleå, Sweden \\ E-mail: diana.chroneer@1tu.se \\ E-mail: anders.segerstedt@1tu.se \\ *Corresponding author
}

\begin{abstract}
This article describes the findings and results from an improvement project concerning a production line at an Ericsson plant in Sweden. The article is a type of a case study that describes activities and discussions in an improvement project. A value stream mapping showed that only a few percent of the throughput time was really adding value to the customer. In an improvement project the involvements of all employees are important. Interviewing and education of workers/operators lead to that they also contribute with suggestions to improve the production flow. Value stream mapping though often classified as a lean technique is a technique for improvements of most kind of productions, here it is applied to a situation that must be classified more agile than lean. A selection of generated, and rather general, solutions were implemented: reduced buffers; more of a 'one-piece' flow; a reduced waiting time by adding work tasks; a more levelled manufacturing and efficient flow was created by a recombination of processes and a reallocation of work tasks. Our article hopefully stimulates students and practitioners to find improvement activities in similar situations and projects.
\end{abstract}

Keywords: value stream mapping; VSM; lean production; agile production; production management; empirical study; electronics industry.

Reference to this paper should be made as follows: Westin, M., Chronéer, D. and Segerstedt, A. (2013) 'Lean assemble-to-order manufacturing at Ericsson', Int. J. Logistics Systems and Management, Vol. 15, No. 1, pp.1-17.

Biographical notes: Maria Westin completed her MSc in Industrial Engineering from Luleå University of Technology in year 2007. Then she started to work as a Production Engineer at Ericsson and continued to work with the improvement project, described here, and its implementation. Later, in 2009, she became a process owner of planning processes. In 2010, she left Ericsson and became a Senior Supply Planner at AstraZeneca. 
Diana Chronéer received her MSc, Lic Tech, Dr Tech all from Luleå University of Technology. Currently, she is a Senior Lecturer and Researcher at Luleå University of Technology in Industrial Logistics with experience and connections to organisation and informatics. Her research has so far been focused on managing innovation and product development in process industries. She has published in and reviewed for different journals: International Journal of Logistics Systems and Management, Product Management Journal, International Journal of Innovation Management among others.

Anders Segerstedt received his MSc, Lic Tech, Dr Tech, Docent all from Linköping Institute of Technology. Since 2004, he is a Professor in Industrial Logistics at Luleå University of Technology. He has experiences from different full-time positions in industry, 1975-1991. He has published in and reviewed for many different journals: International Journal of Logistics Systems and Management, International Journal of Production Economics, International Journal of Production Research, Computers and Operations Research, Supply Chain Management: An International Journal among others.

\section{Introduction and a short literature review}

There is always a need for a company to improve and redesign its supply chain and production system to make the company even more competitive (Schonberger, 1986, 1996; Segerstedt, 1999; Dangayach and Deshmukh, 2001; Childerhouse and Towill, 2006; Serrano Lasa et al., 2009; Pettersson and Segerstedt, 2011). Different improvements require the company to shorten and reduce variability of delivery times, decrease work-in-process and inventories to attain short lead times, decrease variations and disturbances and increase utilisation of production resources.

The lean production paradigm can assist companies achieve goals stated above. The Lean management philosophy has its foundation in minimisation of the resources used in all company activities. The essence of lean thinking is composed of five principles:

1 precisely quantify value in terms of a specific products

2 identify the value stream for each product

3 make value flow without interruptions

4 let the customers pull value from the producers

5 pursue perfection (Womack and Jones, 2003).

The approach involves eliminating waste comprising of unnecessary actions and linking all steps that create value (Hicks, 2007).

Lean production has received ample attention in the literature as well as in practical performance during the last decades. The growing popularity of lean production as an approach, especially in manufacturing companies, is probably largely due to the book Lean Thinking by Womack and Jones (1994) as well as the continued competitive pressure from globalisation (Husby, 2007). Lean production as a concept has evolved over the past two decades and it is applied not only in manufacturing companies, but also in business processes. Shah and Ward (2007) found in their literature review that there 
exist many descriptions of lean production and its underlying components. They observed that the definitions are very general and have become more expansive over time. It now includes just-in-time (JIT) activities, quality improvements, employee involvement, customer focus, kanban, production smoothing, set up time reduction and all process improvement activities.

There is a general agreement that lean production is well suited to companies with similar characteristics as the automotive sector, namely, with low- or medium-complexity products with a relatively stable demand (c.f., Duguay et al., 1997; White and Prybutok, 2001). But, the implementation of lean production in a manufacturing system is a complex task. Lean production system is recommended for products whose demand may be smoothed to be linear with a small slope so that system uncertainties can be easily accommodated (Domingo et al., 2007). Reichhart and Holweg (2007) emphasise that difficulties in adoption of lean thinking can be due to an inherent conflict between lean production techniques and the need to link the production pull signal to variable demand in the marketplace. However, research indicates that there is still a need to explore the implementation and performance relationship with a practical focus (Álvarez et al., 2009).

Mapping the value stream is one critical step to obtain a lean production and should be achieved before any attempt to eliminate wasteful activities (Rother and Shook, 2003). Mapping activities of a process facilitates identification of as well as the value adding as the non-value adding activities. A detailed value stream map will be useful in applying principles of lean production. The non-value adding activities offer the largest opportunity for performance improvement (Womack and Jones, 2003) by eliminating eight major wastes: excess processing; waiting; transportation; inappropriate processing; excess inventory; excess movements; defects; under-utilised people (Liker, 2004).

Braglia et al. (2006) report that value stream mapping (VSM) is not easy to apply in the case of complex production processes with multiple flows that merge. They suggest a new framework by integrating additional tools derived from the manufacturing engineering area. Grewal (2008) shows that that even a small company can make significant improvements by adopting VSM. Wee and Wu (2009) present a VSM from the Ford Motor Company in Taiwan in which they recommend the performance of VSM in four steps: problem finding, idea finding, obstacle finding, and solution finding. Zakuan and Mat Saman (2009) study an automotive component, a car seat, with VSM; they found that the company had to redesign their production system. Serrano Lasa et al (2009) study six companies and illustrate the application of VSM in the redesign and improvement of production systems.

In US in the end of 1980s the fashion industry developed a competition strategy to protect the domestic market from outside low price clothing. The aim of strategy, quick response, was to improve the external efficiency, to do the right things, and quickly, in the total supply chain from raw material to finished product. The members in the supply chain share both risks and advantages of the companion ship through the thinking that the group is stronger than the individual. The production this thinking creates and its concrete realisations that are established in the supply chain are called agile production. For a real company it is difficult, no to say impossible, to always be lean or to always be agile; in the first case the customers would think it is too stereotyped and in the second case too expensive. It is not enough to do the right things, to create external efficiency, to be agile; it is also important to create a cost effective supply chain and production, to have an internal efficiency, to be lean. The key differences between lean and agile relate to the 
positioning of the decoupling point, which separates the part of the supply chain (and organisation) oriented towards customer orders (the agile side) and the part of the supply chain based on forecasts, planning and cost effective production (the lean side) (Naylor et al., 1999; Gunasekaran, 2001; Stratton and Warburton, 2003; Segerstedt, 2009).

This paper describes the findings and results from an improvement project concerning a production line at an Ericsson plant in Sweden. The aim of the project was to improve production by shortening lead times, decreasing variability in delivery times, reducing inventories, consuming less resources and lowering costs. 'Lean theory' and 'lean paradigm' were, and still are, very popular for practitioners in Swedish industry. From Ericsson's point of view, and their employees, the application of lean theory was outspoken, suitable or not, in the project presented in this paper and with a focus on a specific production section. The project was from the beginning a part of the first author's master thesis (Westin, 2007), and Maria Westin continued to work at Ericsson as engineer and system analyser of logistics and production. The project started with an investigation of perceived problems, buffers and inventories, and obstacles at the case company. The study was carried out according to four phases: problem finding, idea finding, obstacle finding and solution finding (Wee and $\mathrm{Wu}, 2009$ ). The production and material flow in focus was downstream the customer order decoupling point (the orders mostly came from Ericsson's own sales organisation but behind those there existed also an external customer). The production of mediumcomplexity products with an unstable demand was studied and improved with a "lean accessory'. Therefore the production can be classified as an agile production (cf., Christopher and Towill, 2000, 2001). The project identified and separated activities in non-value adding and value adding activities, wasteful activities were handled as opportunities to improve the processes.

The remaining sections of this paper are organised as follows. Section 2 presents the situation in the production system when the improvement project started. Section 3 describes the found ideas and opportunities for improvements, it contains a lot of 'should' and 'would' deliberately. This section hopefully inspires the readers to find similar improvements in their own production. Section 4 describes the first established wished future state for an intended development. The final Section 5 describes what happened after the first wished future state and during the first couple of years. Rather general findings and conclusions from this improvement project is also presented in the final section.

\section{The studied product family, the production flow, and its VSM}

\subsection{Product family}

The product family in the case was radio base stations that forward the signals of telephone calls to final destinations via radio waves. It was a high volume product with product variants distinguished by degree of content, armament, frequency of transmission, and configuration specified by customers. Therefore, there were a high variety of end-items within this product family. 


\subsection{Production flow}

The manufacturing was divided into three sequential flows (Figure 1). The first part was composed of two identical assembly lines where the armament and the cabling are assembled. A cabinet, which was the base of the product, was transported from a local hub directly to the production. The assembly was then performed sequentially at several stations. The cycle time here was adjusted to the bottleneck identified in the last two assembly stations (stations with a work content that requires the longest operation time).

The second part consisted of a test area. Here, the operability of the radio base stations was confirmed. A large number of test machines denoted an excess capacity. In addition to the net test time in the test machines, manual activities were required to transport the radio base station, to connect and to disconnect to the test machines and record the tests results.

Finally, the manufacturing flow ended with a final inspection station, a station for assembly of doors and a packing line for the product packaging. The packing process also included records of product data for traceability which was called package reporting.

Figure 1 The three main process steps of the production flow (see online version for colours)

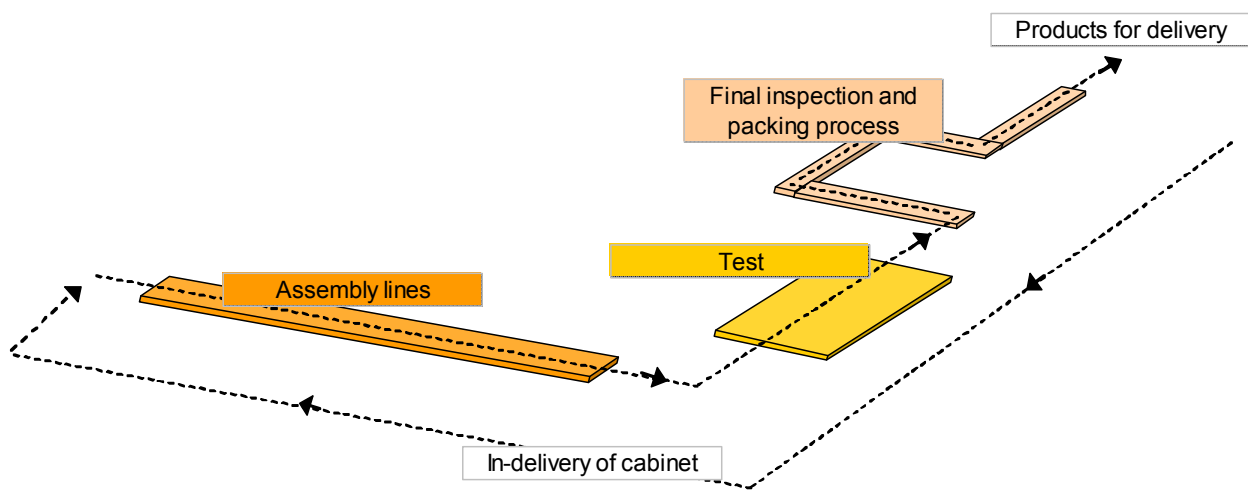

The production planning was constructed on a weekly basis and the daily production schedule was usually established the day before the planned production. Priorities were given to orders with the earliest delivery date and orders were then batched by product type. The demand could vary substantially within a short time horizon. Changes from previous forecasts also caused problems at the suppliers, i.e., to deliver the components on time. The situation of materials, shortages or not, made the production planning difficult and the production plan could not be settled before the intended day.

\subsection{The VSM}

The VSM of the improvement project resulted in a descriptive map of material and information flow, showing that less than $10 \%$ of the throughput time was strictly adding value to the customer. The identified non-value adding activities are clarified in Figure 2 and could be separated into wasteful non-value adding activities or necessary non-value adding activities. 
Figure 2 The identified non-value adding activities (see online version for colours)

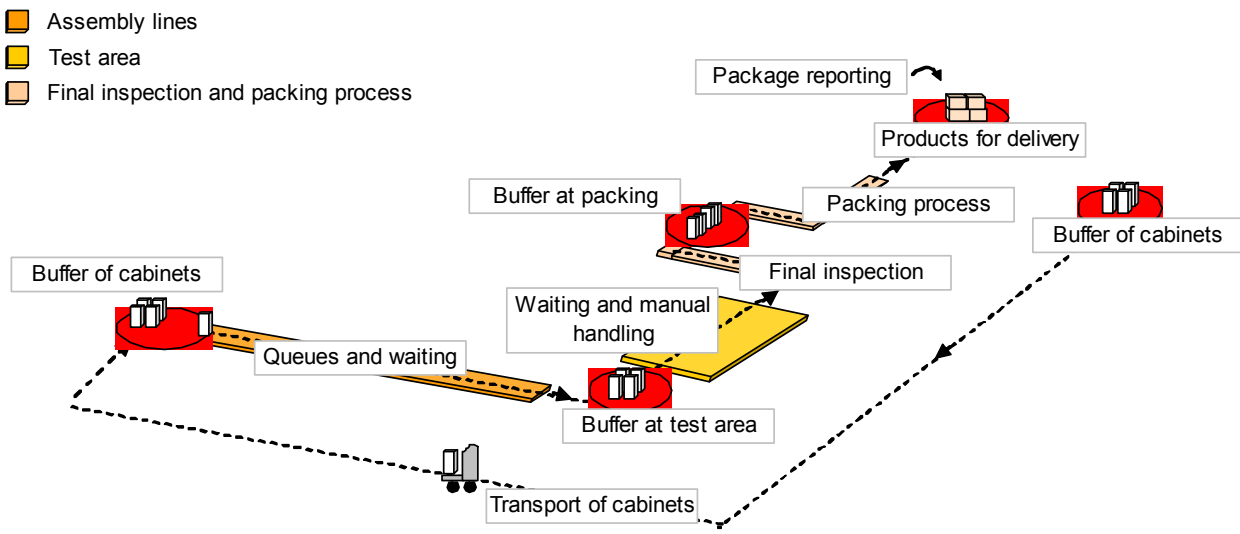

Wasteful non-value adding activities were identified as follows:

- Excesses. Excess inventory was exposed at the buffer of cabinets, the buffer of radio base stations in front of the test area, the buffer at the packing area and at the buffer of produced radio base stations waiting for delivery. Buffers consumed valuable floor spaces; increased the throughput time and tied up material resources. The buffer at the test area also hid defective products and delayed feedback to the source of error for a corrective action (cf., Liker, 2004). Excess work-in-process also occurred at the assembly line as in work-in-process inventory. It created a longer throughput time than necessary and inventory carrying costs. Queues of products were generated between the assembly stations and caused feedback delays concerning incorrect assembling. The amount of work-in-process was a direct result of excess processing (Womack and Jones, 2003). The last two assembly stations, identified to be a bottleneck, had a limiting capacity for only one of the three variants in the product family; therefore frequent balance delay was created. The balance delays, created by uneven workload at the assembly stations, resulted in queues of products. The total excess work-in-process blocked the system, reduced new sales opportunities and profitability (cf., Daine et al., 2011).

- Waiting. Waiting was observed at the assembly line and technicians were found to be idle in the test area during the automated test time. In addition to queued up work-in-process, the balance delays resulted in idle time for workers at the assembly stations with less workload. Due to long automatic test times, waiting occurred for the technicians. Waiting tied up valuable labour and was identified as a waste of resources. 'Waiting at a bottleneck station is lost manufacturing times' (e.g., Krajewski and Ritzman, 2005).

- Rework. Rework is the result of incorrect assembly or defect components. The rework in the case was achieved at the assembly line or the product was taken to the side which caused unnecessary hold-ups in the production. This can be denoted as capacity losses according to Liker (2004).

To eliminate necessary but non-value-adding activities, the current situation should be improved on a long-term basis (cf., Womack and Jones, 2003). The necessary but non- 
value adding activities, for the customers, were classified as follows: transports of cabinets, manual activities at the test area (it was necessary to test the functionality), packing

(it was required for delivering the radio base stations to the customers), package reporting (it was required to be able to track the individually product). The test of the functionality was considered to be a value adding activity since customers required it and it was a competitive advantage for the company.

\section{Opportunities of improvements from the current state}

\subsection{Eliminate buffer of cabinets at in-delivery}

The buffer of cabinets was set up to avoid shortages. A number of cabinets were necessary to ensure the production so that the buffers could not be eliminated but reduced. Cabinets were delivered to the factory several times per working shift in order to reduce the buffer of cabinets. The floor space for a buffer of cabinets in front of the assembly lines was large enough to serve the two assembly lines, with the same frequency of deliveries. The buffer of cabinets at in-delivery could be eliminated (see Figure 3). This elimination could free inventory and floor space and hence reduce capital tied up in unnecessary buffers. The staffs that unloaded the truck could transport the cabinets directly to the assembly lines. This would free transport resources to other work opportunities.

Figure 3 The outcome of eliminating the buffer of cabinets at in-delivery (see online version for colours)



There were two types of cabinets. To enable delivering the right type of cabinet there should be a fixed production plan developed in advance, before the scheduled production day, which was not the case at the time of the study. A system for replenishment of cabinet should be established to secure the production, regardless of takt time. Takt time is the pace, demand rate, the market requires the products. A simple approach to obtain takt time is a fixed time interval for deliveries where the right amount of cabinets is 
ordered. A tool showing which amount of cabinets to order in different situations, varying with takt time would facilitate the replenishing.

\subsubsection{Decrease excess processing and waiting time at assembly lines}

The amount of workload differed between the assembly stations and between product types at the same assembly station, resulting in different cycle times between various assembly stations and also between different product types. The cycle time variations were also related to which assembly workers performed the job. This was an indication of lack of standardised work. The different armament of the product types caused balance delays. Additional balance delay causes could be derived from the limited space for the material at the assembly stations and the fact that specific work elements should be performed at the specific assembling stations. One reason for the lack of standardised work was the employment of staffing companies which led to frequent replacements of staff. Problems with the material deliveries to the assembly line also caused interruptions. A proper and efficient production schedule could not be prepared due to material shortages.

Variation in cycle times resulted in queues of products in front of the assembly stations with a relative long cycle time and a waiting at the assembly stations with a relative short cycle time. Queues were generated due to different operation times and different number of operations to be performed at the different assembly stations; it can be reduced by levelling and synchronising the production line (Shingo, 1992). Long waiting times can also arise at the assembly lines when there is shortage of material or components. Waiting time can be utilised to improvements, learning, 5S processes (Seiri, Seiton, Seiso, Seiketsu and Shitsuke) and 'kaizen' (Hines et al., 1998). A pull method could be established where the radio base stations were assembled at a takt time and the balance delays can be reduced by levelling the workload to achieve more of a 'one-piece-flow' and higher productivity.

\subsection{Line balancing and extended cycle time}

Compared to the conceived bottle neck (at the two last assembly stations); the cycle time at several assembly stations were significant shorter but also longer at some assembly stations. To divide the real production time with the shortest needed takt time and provide the resulting numbers of work stations with exactly uniform amounts of workload presents the optimal balancing (Krajewski and Ritzman, 2005). The circumstances did not allow an optimal balancing of the assembling lines. The circumstances of a production line in general often make it hard to bring it into total balance (Segerstedt, 2009).

An adjustment of the cycle time and a levelling of the workload would reduce the balance delay and enable an optimisation of the number of assembly workers (assemblers) at the different assembly stations. An extended cycle time would satisfy assembly stations with a need of a longer cycle time and the assembly stations with shorter cycle times could merge and be managed by one worker instead of two workers. Comparing the balance delays of the current case situation with a prolonged cycle time showed an average reduction of $12 \%$ (cf., Figure 4 ). With a prolonged cycle time the varying need of assembly workers due to product variants was levelled. An extended cycle time would increase the productivity, but also reduce the throughput level. An 
extended cycle time, to the amount suggested, would still satisfy expected demand. This was confirmed through historical data analysis.

Due to different product types, the staffing of the assembly stations differed, both in positions and in the number of assembly workers. In line with the personnel policy of Toyota the line coordinator, production leader or other available personnel, could cover the varying need of assembly workers (Shingo, 1992). As an alternative, an additional worker can acts as an assembly worker when there is a need but who otherwise acts as a team leader involved in improvement work.

Figure 4 An example how an extended cycle time can reduce the balance delay (see online version for colours)

Current situation



Extended cyletime

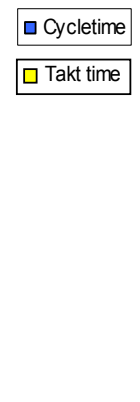

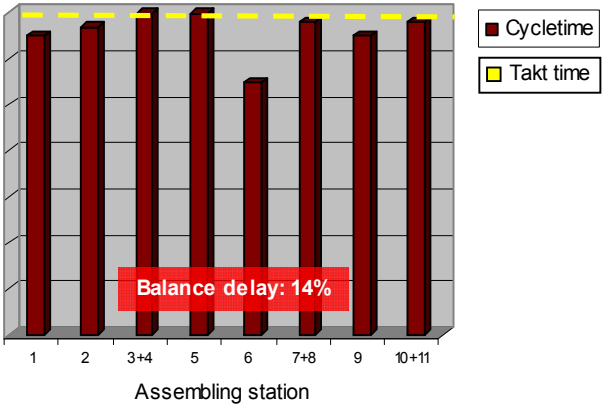

\subsection{Specific lines for different product variants}

The product types with the least workload contributed to the greatest balance delay. To adjust one of the assembly lines for the product type with the least workload, and to keep the other line for production of remaining variants, could reduce the balance delay. But, it could increase the risk that the demand of one product type could exceed the maximum capacity of the assembly line.

\subsection{Pull methods in assembly}

The length of the assembly line restricted the amount of work-in-process. A pull method of workflow could be implemented to pull the products from the downstream production step, and not pushed from the upstream production step. A pull method would minimise the work-in-process. Cooperation between 'neighbours' at an assembly line could enforce a pull method of workflow.

Toyota has two policies of cooperation:

1 you are not allowed to pass the product until the following worker has finished and is ready for the next coming product

2 a zone between two workstations with shared work elements are utilised.

The workers upstream respectively downstream the zone is responsible for the shared work elements. If the upstream worker is delayed the shared work elements are 
performed at the downstream station. If the worker upstream to the zone is idle he should perform the shared work elements (Shingo, 1992).

The first of the policies seems easier to apply; but the second policy of cooperation means a possibility of passing products when assembly remains. That will increase the efficiency by reducing smaller production stops and getting a 'floating' levelling of workload. Shared work elements require a good communication. The work element should be uncomplicated like cabling or screwing. For the assembly workers to keep the takt time a form of takt holder would be valuable.

\subsubsection{Decrease demand variations and make capacity planning possible}

The promised short delivery times were a main reason why the production met varying demand. If customers, mostly Ericsson's own sales organisation, would place orders more in advance; the orders could be levelled and allow a better production and capacity planning. A smoother demand and a possible planning in advance also could make it easier for suppliers and it would reduce the risk of material shortages. Longer lead times could also reduce transportation costs through deliveries gathered together, co-distribution. In general, longer delivery times that are fulfilled create a better customer service than short delivery times that are not fulfilled.

A rather high percent of the working hours was set aside for interruptions and it was excluded from production. Time reservation for production stops could contribute to great capacity losses. According to Toyota Production System there should be an idle time interval between two shifts. The time interval is to increase the capacity by means of overtime (Shingo, 1992). Replacing these percent exclusions with a time interval between the shifts would increase possible available production time; then extra demand or unplanned production stop more easily could be handled by overtime.

The production volumes were low during some periods and the capacity of one of the assembly line could then be enough to cover demand. This would lead to an opportunity to eliminate one of the assembly lines and to free space for other activities. However, this was not recommended since periods with high volumes must then be covered with an increased number of working hours per day and possible night shift. An increase of the working hours per day also would increase costs, both direct and indirect costs, and time must then be spent on negotiations and agreements with the work unions to change the number of working hours. Two assembly lines created more flexibility for the product types and possible new future product types.

\subsubsection{Minimise buffer of products and waiting time at the test area}

The queue or buffer in front of the test area was mostly very large. It should be limited to prevent excess work-in-process and to a delayed feedback of defective products. A reduced queue or buffer would then enable a continuous flow and reduce the total throughput time, also the need for storage spaces would be reduced and a more rapid feedback of defect products would take place.

Psychological reasons, as stress or anxiety, may sometimes also create inventories. To eliminate inventories due to psychological reasons, the explanation to the behaviour of the workers must be found (Shingo, 1992). A large queue before the test was mostly not dependent on large production batches or difficult frequencies to test. It appeared that the 
knowledge and the belief of excess capacity in the test area, many test machines, generated a fraudulent calmness and an inactivity even though the queue in front of the test area was disgracefully large. The excess test capacity should function as a possibility to absorb a generated congestion and not as a possibility to buffer.

A number of test machines were not capable of testing a specific frequency. Therefore, large batches of this specific frequency should be avoided. In this area, the yield varied and the percent of the products passing the tests fluctuated. Therefore, congestion in front of the test area could occur but it should also be eliminated as soon as possible.

\subsection{Pull methods between test area and assembly lines}

The length of the line between the assembly lines and the test area restricted the test buffer. A number of radio base stations waiting to be tested should have an upper limit or the line should be shortened to a desirable length. A fixed number of radio base stations should be allowed as a buffer. If the buffer would reached the maximum level the assembly lines should stop. A defect component will often be followed by another defect component. A large number of radio base stations with defect components could then be hidden in the test buffer before the problem would be exposed in the tests and the assembly could be stopped. Therefore, a reduced buffer would expose problems and enable an immediate feedback for a correction.

When the buffer was overloaded but it was not the number of test machines that restrained the capacity, a worker usually in the assembly could move and start to operate the additional test machines. The takt time of the assembly lines would decrease and the test buffer could be absorbed without a major production stop.

\subsection{Separate man from machine}

The priority in the test area was to occupy the test machines and not the technicians. Waiting time, when workers were monitoring automatic machines, was identified as a waste of resources. An important factor in lean production is to separate man from machine. Instead of monitoring the machines the operators should operate several machines and keep them all running (Shingo, 1992). The test machine automatically did a part of the test time and a technician was not required. To implement a work procedure where one man operates several machines the waiting time of the technicians could be reduced and the productivity would increase. The remaining waiting time should be used to perform manual work elements at available products and test machines.

\subsection{Additional activities in test area}

Waiting time should be used to do maintenance, kaizen or other value adding activities (Hines et al., 1998). An alternative to increase the number of test machines per technician would be to introduce value-adding activities during the automatic test time. Assembling the door of the radio base station during the automatic test time would add value to the product and at the same time eliminate a task from the packing process. It would be possible in terms of time but there are difficulties with the narrow space in the test area 
and to make the door assembly in an ergonomic correct way. An alternative could be to perform the final inspection at the test area. Either by the technicians or by one responsible of all radio base stations. The total productivity would increase and the total throughput time would be reduced. Alternatively one responsible operator performs the inspection but at the test area during test time. This would still mean a reduced total throughput time.

\subsubsection{Improve the packing process}

The buffer in front of the packing process hindered a continuous flow and increased the throughput time. In addition to the packing the workers had other tasks. The workers themselves decided when to perform the packing, which resulted in an intermittent work. This also resulted in a buffer in front of the packing but also a buffer of packed products waiting for delivery. The buffers occupied area and tie up capital. The packing process was also affected by the intermittent work at the test area. A more frequent packing would level the capacity and create a more continuous flow.

\subsection{Organise the packing process}

Specific intervals of time when the workers are fixed to the packing process should be established. This would bring a structured way of working, where the buffer in front of the packing could be reduced and an unnecessary large number of products waiting for delivery could be avoided. As an alternative an upper limit of products preceding the packing line can be established. When the limit is reached the workers should start the packaging process.

\subsection{Package reporting}

A report of the packaging was performed prior to the delivery of packed radio base stations. The package reporting was an additional reason for the congestion and the buffer of packed products. The workers at the packing line should be educated to and authorised to perform the package reporting. If the delivery of product information from the final inspection station would be transferred electronically it would create better conditions for the packing personnel to perform the package reporting. A more efficient and quicker package reporting would create a direct flow to delivery and the buffer of packed products could be reduced. However, it would require standardised work and established working routines; which also would prevent unnecessary stress situations for the workers.

\subsection{Door assembly}

At one of the product type, a board had to be attached to the door. This would lead to an increased cycle time. In order to facilitate a continuous flow, the board could be attached when the cabinets are unpacked and the door is lifted off. This would level the cycle time of the product types. An alternative is to outsource the board attachment to the supplier that produces the cabinet. 


\section{A wished future state}

\subsection{Summary of wished improvements}

The VSM resulted in a descriptive map of the material and information flow which showed that only a low percent of the throughput time was really adding value to the customer. The value stream analysis of the, then prevailing, current situation resulted in and indicated some suggestions for improvements, described above. Buffers could be reduced and waiting time eliminated. A workflow should be applied where products were manufactured at a takt time, at a pace the customers and the market require. More of a one-piece-flow and limited and decreased buffers should control the work in process. These changes would reduce lead time and inventory costs and the value adding parts would increase with a considerable amount. Shorter lead times and a production flow with fewer variations could facilitate estimations of more correct promised delivery time and then also deliver on time. Clear routines in combination with reduced buffers and work in process would also result in a more structured and a safer work environment. Reduced buffers and inventories also make warehousing less complicated.

\subsection{A wished future state}

The goal with the study was to eliminate activities that did not add value to the product and to develop stable and predictable processes. The concept of lean urges an ideal state where the total value stream is a continuous flow producing at the takt time, the amount of work-in-process is minimised and the products flow at the pull of customer.

Figure 5 A wished future state



A wished future state was established, Figure 5. The fluctuating demand causes a varying takt time and a varying requirement of workers from one day to another. A comparison of the current and a future state was achieved at the same situation as the VSM took place. In the future state the cycle time was extended and every process step was adjusted to minimise the balance delay. At the current situation the production was running 2 shifts per work day. At the future state the same production volume is met, with 1 shift per working day and $11 / 2$ assembly line.

At the future state the productivity is increased. A pull method of flow, limited buffers and more of a one-piece flow through the assembly reduce the work-in-process. Problems will be exposed and their causes identified. The throughput time and the tied up capital is reduced. The buffer of cabinets is reduced to fractions of its original size. A 
reduced utilisation of surfaces will result in a more open and structured work environment. It will also make spaces for an atomisation of the packing line. The throughput time can be reduced with a considerable amount of hours. A shorter throughput time will be easier to estimate and it can create a more stable flow and better opportunities for a high precision in deliveries. An efficient flow put the company in a position requiring efficiency and can generate creativity resulting in improvements. Reduced buffers and work-in-process, standardised work and clear routines will create a more structured and safer working environment. The production plans at a future state established the day before they are executed, with material on hand; daily adjustments should be avoided. It will be necessary to reduce the buffer of cabinets but also to optimise the number of workers in the production, instead of securing it with excess capacity. The production planning will consider the entire production flow, and not isolated processes. To utilise available production time the interference eliminator of a certain percent of the working hours will be eliminated. Further, production interruptions will be met with overtime.

\section{What happened afterwards; findings and conclusions}

Time has passed, many months even some years, since the study was carried out and the production of radio base stations has undertaken great changes. The map of the current state illustrated a snapshot of the then current production status and wishes. It could not be reached instantaneously, and it required a continuous up-dating due to achieved improvements and changed production status. To control if the work of improvements developed in the right direction, there have been a continuous measuring of critical factors, e.g., delivery precision, work-in-process, utilisations and lead times. Improvements have been implemented methodically according to the ruling wished future state. The improvements of the processes resulted in quantitative but also qualitative progress. An important factor for improvements was that vast number of product variations was questioned and reduced. A narrower and decreased product flora facilitated the production planning and it made a levelling of orders possible. An increased number of standardised components reduced the amount of product types. Operators were educated to perform different and complementary tasks of the manufacture. The amount of hired temporary personnel was decreased; regular staff took their place instead. Less material placed at inventories and at the assembly lines reduced costs of warehousing and increased space utilisation, days of inventories decreased and the lead time through the production line decreased with more than $50 \%$. The improvements in the assembly production of the radio base stations and its material flow were so substantial that time for alternative production came up. Therefore, another production site was closed down and its production of products was moved and incorporated in the studied production facility reported in this paper. Due to the changes, new products and a focus on efficient use of spaces, the production system and layout has been modified compared to what is presented in Section 2 and Section 3. Changes in customers' preferences and strives for efficient production require continuous measurements of performance and recurring redesign of the production system and its supply chain (cf., Zakuan and Mat Saman, 2009; Serrano Lasa et al., 2009; Pettersson and Segerstedt, 2012). 
Some general findings can be concluded from this improvement project. In an improvement project, the involvements of all employees are important. In this case, clear information of the purpose with the project, interviews and education of workers/operators led to that they contributed with suggestions on how to improve the production flow. They had the 'real knowledge' of the 'micro' details of their operative work from which they could suggest important improvements; both smaller 'kaizen' improvements and greater 'business reengineering process' improvements. In a production line similar to this case, with high variations in operations times depending on what product or variant manufactured, it is important to train and educate operators to manage many different parts of the manufacture. They can then be flexible and operate in other parts of the production line where increased capacity is needed to enable a level flow. This move should be authorised by the operators themselves, and be signalled by small restricted buffers. This training of operator behaviour is difficult to establish with hired temporary personnel, which is also a reason why the amount of workers from staffing companies had decreased. Uncertain and dynamic demand require stable and efficient supply responses, and with long production cycles it is essential to speed up overall processing times (cf., Tomino et al., 2011). The large buffers of yesterday 'darkened' the need of extra capacity in other parts of the production line and gave the operators a sense of security that there was no reason to hurry. It should not be allowed for an operator, or skilled technician, to sit and watch a machine (or test equipment) work. A long cycle time will instead be used such that the operator performs another task of manufacture; it is better the machine waits for the operator than the opposite. It is important to increase standardisation, to reduce number of unnecessary product variants; it reduces the complexity in the material flow.

In sum, to improve efficiency in production it is necessary to start with a complete analysis of the present situation; how material and information flows and how it is controlled. To eliminate all unnecessary tasks is an easy way to rationalise and achieve efficient production, but to identify the unnecessary and convince people what is necessary and what is not, that is difficult (cf., Segerstedt, 1999). A natural way to improve efficiency in production is by separating the production in value adding and non-value adding activities, this despite if the production is classified as lean or agile. Therefore, VSM though often classified as a lean technique is a technique for improvements of most kind of productions. Here, it is applied it to a situation that must be classified much more agile than lean. This is in accordance with Slomp et al., (2009) who investigate how lean control principles can be used in a make-to-order job shop, where volume is typically low and has a high variety. Further, research indicates that there is a need to be flexible even though the company has a lean thinking philosophy (Pil and Fujimoto, 2007).

The intention of the paper is to contribute with solutions and examples of how to streamline organisations. A selection of generated solutions were implemented; reduced buffers of cabinets; more of a 'one-piece' flow; a reduced waiting time by adding work tasks; a combination of processes and a reallocation of work tasks to achieve a more levelled manufacturing flow. Hopefully, companies and students in similar situations can use this study as an inspiration to improve their situation both when it can be called lean or agile production. 


\section{Acknowledgements}

The authors are thankful for valuable comments from reviewers. The authors also thank Ericsson for allowing presentations of aggregate details of this project and its result.

\section{References}

Álvarez, R., Calvo, R., Peña, M. and Domingo, R. (2009) 'Redesigning an assembly line through lean manufacturing tools', International Journal of Advanced Manufacturing Technology, Vol. 43, Nos. 9-10, pp.949-958.

Braglia, M., Carmignani, G. and Zammori, F. (2006) 'A new value stream mapping approach for complex production systems', International Journal of Production Research, Vol. 44, Nos. 18-19, pp.3929-3952.

Childerhouse, P. and Towill, D.R. (2006) 'Enabling seamless market-orientated supply chains', International Journal of Logistics Systems and Management, Vol. 2, No. 4, pp.357-370.

Christopher, M. and Towill, D.R. (2000) 'Supply chain migration from lean and functional to agile and customized’, Supply Chain Management: An International Journal, Vol. 5, No. 4, pp.206-213.

Christopher, M. and Towill, D.R. (2001) 'An integrated model for the design of agile supply chains', International Journal of Physical Distribution \& Logistics Management, Vol. 31, No. 4, pp.235-246.

Daine, T., Winnington, T. and Head, P. (2011) 'Transition from push to pull in the wholesale/retail sector: Lessons to be learned from lean', International Journal of Logistics Systems and Management, Vol. 8, No. 2, pp.214-232.

Dangayach, G.S. and Deshmukh, S.G. (2001) 'Manufacturing strategy literature review and some issues', International Journal of Operations and Production Management, Vol. 21, No. 7, pp.884-932.

Domingo, R., Alvarez, R., Peña, M. and Calvo, R. (2007) 'Materials flow improvement in a lean assembly line: a case study', Assembly Automation, Vol. 27, No. 2, pp.141-147.

Duguay, C.R., Landry, S. and Pasin, F. (1997) 'From mass production to flexible/agile production', International Journal of Operations and Production Management, Vol. 17, No. 12, pp.1183-1195.

Grewal, C. (2008) 'An initiative to implement lean manufacturing using value stream mapping in a small company', International Journal of Manufacturing Technology and Management, Vol. 15, Nos. 3/4, pp.404-417.

Gunasekaran, A. (2001) Agile Manufacturing: The 21st Century Competitive Strategy, Elsevier Science, Oxford.

Hicks, B.J. (2007) 'Lean information management: understanding and eliminating waste', International Journal of Information Management, Vol. 27, No. 4, pp.233-249.

Hines, P., Rich, N. and Hittmeyer, M. (1998) 'Competing against ignorance: advantage through knowledge', International Journal of Physical Distribution \& Logistics Management, Vol. 28, No. 1, pp.18-43.

Husby, P. (2007) 'Becoming lean', Material Handling Management, August, pp.42-45.

Krajewski, L.J. and Ritzman, L.P. (2005) Operation Management-Processes and Value Chains, Prentice Hall, New Jersey.

Liker, J.K. (2004) The Toyota Way - 14 Management Principles from the World's Greatest Manufacturer, CWL Publishing Enterprises, Madison.

Naylor, J.B., Naim, M.M. and Berry, D. (1999) 'Leagility: integrating the lean and agile manufacturing paradigms in the total supply chain', International Journal of Production Economics, Vol. 62, Nos. 1-2, pp.107-118. 
Pettersson, A.I. and Segerstedt, A. (2011) 'Performance measurements in supply chains within Swedish industry', International Journal of Logistics Systems and Management, Vol. 9, No. 1, pp.69-88.

Pettersson, A.I. and Segerstedt, A. (2012) 'Measurements of excellence in a supply chain', International Journal of Logistics Systems and Management, Vol. 13, No. 1, pp.65-80.

Pil, F.K. and Takahiro, F. (2007) 'Lean and reflective production: the dynamic nature of production models', International Journal of Production Research, Vol. 45, No. 16, pp.3741-3761.

Reichhart, A. and Holweg, M. (2007) 'Lean distribution: concept, contributions, conflicts', International Journal of Production Research, Vol. 45, No. 16, pp.3699-3722.

Rother, M. and Shook, J. (2003) Learning to See - Value Stream Mapping to Add Value and Eliminate Muda, The Lean Enterprise Institute, Brookline.

Schonberger, R.J. (1986) World Class Manufacturing: The Lessons of Simplicity Applied, The Free Press, New York.

Schonberger, R.J. (1996) World Class Manufacturing: The Next Decade: Building Power, Strength, and Value, The Free Press, New York.

Segerstedt, A. (1999) 'Escape from the unnecessary - some guidelines for production management', Production Planning \& Control, Vol. 10, No. 2, pp.194-199.

Segerstedt, A. (2009) Logistik med fokus på material och produktionsstyrning (in Swedish: Logistics with focus on Material and Production Control), Liber, Malmö.

Serrano Lasa, I., Castro, R. and Laburu, C.O. (2009) 'Extent of the use of lean concepts proposed for a value stream mapping application', Production Planning \& Control, Vol. 20, No. 1, pp.82-98.

Shah, R. and Ward, P.T. (2007) 'Defining and developing measures of lean production', Journal of Operations Management, Vol. 25, No. 4, pp.785-805.

Shingo, S. (1992) Den nya Japanska produktionsfilosofin (in Swedish: The new Japanese Philosophy of Production), TQM Produktionsskolan AB, Åre (A rework and translation to Swedish by Sødahl, L-O.

Slomp, J., Bokhorst, J.A.C. and Germs, R. (2009) 'A lean production control system for highvariety/low-volume environments: a case study implementation', Production Planning \& Control, Vol. 20, No. 7, pp.586-595.

Stratton, R. and Warburton, R.D.H. (2003) 'The strategic integration of agile and lean supply', International Journal of Production Economics, Vol. 85, No. 2, pp.183-198.

Tomino, T., Hong, P. and Park, Y. (2011) 'An effective integration of manufacturing and marketing system for long production cycle: a case study of Toyota Motor Company', International Journal of Logistics Systems and Management, Vol. 9, No. 2, pp.204-217.

Wee, H.M. and Wu, S. (2009) 'Lean supply chain and its effect on product cost and quality: a case study on Ford Motor Company', Supply Chain Management: An International Journal, Vol. 14, No. 5, pp.335-341.

Westin, M. (2007) Värdeflödesanalys vid Ericsson (in Swedish: Value stream mapping at Ericsson), p.198, Master thesis, Luleå University of Technology, Luleå.

White, R.E. and Prybutok, V. (2001) 'The relationship between JIT practices and type of production system', Omega the International Journal of Management Science, Vol. 29, No. 2, pp.113-124.

Womack, J.P. and Jones, D.T. (1994) 'From lean production to the lean enterprise', Harvard Business Review, March-April, Vol. 72, No. 2, pp.93-103.

Womack, J.P. and Jones, D.T. (2003) Lean Thinking: Banish Waste and Create Wealth in your Corporation, Free Press Business, London.

Zakuan, N. and Mat Saman, M.Z. (2009) 'Lean manufacturing concept: the main factor in improving manufacturing performance - a case study', International Journal of Manufacturing Technology and Management, Vol. 17, No. 4, pp.353-363. 